\title{
Co znamená být slovenským Rusínem? Proměna etnické identity rusínské menšiny na Slovensku*
}

\author{
PETR KOKAISL**
}

What Does it Mean to Be a Slovakian Ruthenian?

A Change in Ethnic Identity The Ruthenian Minority in Slovakia

\begin{abstract}
This study focuses on the manifestations of ethnic identity of the Ruthenian population living in today's Slovakia. This identity was (and still is) characterised by a relatively low divergence from the separate ethnicity, religion and language of the region. The study shows the change in ethnic identity together with the main recorded cultural elements from the 19th Century (based on references from literary sources and periodicals) to the present day (using data from qualitative field work). Ruthenian ethnic identity was primarily shaped by religion based on eastern rites which to a greater extent also formed other specific elements of Ruthenian culture - the use of language, celebration of holy days, adherence to fasting rules which were often combined with a specific cuisine. This paper also focuses on the reasons why according to official statistics there has been a significant increase in the Ruthenian population though it does not totally correspond to actual manifestations of Ruthenian ethnicity.
\end{abstract}

Keywords: Ruthenian population; Slovakia; minority; ethnic identity; Ruthenian culture

DOI: $10.14712 / 23363525.2017 .40$

\section{Cíl studie}

Cílem této studie je ukázat proměnu etnické identity slovenských Rusínů na významných historických bodech od 19. století až po současnost (rusínské obrození v Uhrách, vystěhovalectví do zámoří, vznik Československé republiky, události spojené s druhou světovou válkou, politické uvolnění v 60. letech 20. století, normalizace, období po roce 1989). Práce se zaměřuje jak na hlavní prvky, které rusínskou identitu tvoří, tak i na sílu těchto prvků v závislosti na politické konstelaci v určitém politickém období.

Předložený text si klade za cíl odpovědět na tyto otázky: Jakým způsobem se měnila rusínská etnická identita na území dnešního Slovenska? Jaké vnější faktory nejvíce působily na proměnu identity? Jaké hlavní kulturní prvky v minulosti a v současnosti utvářely a utvárí etnicitu rusínského obyvatelstva na Slovensku? Jaké prvky rusínské kultury se v průběhu času nejvíce měnily?

Primární údaje publikované $\mathrm{v}$ této studii vycházejí $\mathrm{z}$ autorova střednědobého terénního výzkumu rusínské minority v roce 2015 v okrese Snina a výzkumů s kolektivem

\footnotetext{
* Tento článek vznikl za podpory IGA PEF ČZU (č. 20161020).

** Petr Kokaisl, Provozně ekonomická fakulta ČZU v Praze, Kamýcká 129, 16521 Praha. E-mail: pkokaisl@ seznam.cz.
} 
studentů oboru Hospodářská a kulturní studia v letech 2014-2015 v okresech Stará L’ubovňa, Bardejov, Svidník, Stropkov, Medzilaborce a Snina [Došková et al. 2015]. Při terénním výzkumu byl nejvíce využíván polostandardizovaný rozhovor, při němž byli respondenti vedeni k označení hlavních prvků jejich rusínské etnické identity. Snahou bylo postihnout co nejširší spektrum respondentů, kteří sami nějakým způsobem deklarovali př́islušnost k Rusínům. Respondenty se stali zaměstnanci řady muzeí a skanzenů, univerzitních pracovišst (Ústav rusínskeho jazyka a kultúry), duchovní, představitelé obecních samospráv, obyvatelé rusínských obcí.

\section{Rozdělení odborné literatury podle chápání rusínské etnické identity}

Vědecké práce, které se zaměřují na rusínskou etnickou identitu, můžeme dělit i podle toho, jak jejich autoři skupinu Rusínů chápou a chtějí vidět. V současnosti převládají ti, kteří považují Rusíny za samostatný národ, jenž se dělí na další podskupiny (Huculové, Lemkové, Bojkové). Zřejmě nejznámějším autorem zastávajícím v tomto ohledu jednoznačné stanovisko je Paul R. Magocsi, který ve své publikaci Národ odnikud [Magocsi 2014] dokazuje, že rusínské etnikum mělo vyhraněnou etnickou identitu již v 1. tisíciletí n. l., kdy docházelo k formování evropských národních států. Podle Magocsiho je kromě dalších kulturních prvků Rusínů specifická a významná i architektura jejich kostelíků. Celá řada především ukrajinských autorů má rovněž zcela jednoznačné stanovisko, ale opačné - Rusíni jsou podskupinou (subetnosem) ukrajinského národa. Zde je možné jako prŕklad jmenovat práci Etnické charakteristiky Rusínů [Marčuk - Marčuk 2012], ve které si autoři všímají nárůstu politických aktivit Rusínů v posledních dvaceti letech. Požadavky na uznání rusínské národnosti a jazyka považují za rusínský separatismus a snahu Rusínů vytvořit bud’ nezávislý stát, nebo alespoň autonomní republiku Podkarpatskou Rus.

Kulturními prvky majícími vliv na etnickou identitu slovenských Rusínů a jejich proměnu od konce druhé světové války do současnosti se zabývají publikace autorů Mariána Gajdoše a Stanislava Konečného Postavenie Rusínov-Ukrajincov na Slovensku v rokoch 1948-1953 a Rusíni a Ukrajinci na Slovensku v procesoch transformácie (1989-1995) [Gajdoš - Konečný 1994, 2005]. Autoři poukazují na skutečnost, že se rusínsko-ukrajinskému obyvatelstvu dostávalo značné podpory ze strany státu, což ale způsobilo, že se netransformovalo na samostatný a životaschopný etnosociální subjekt. V období samostatného Slovenska se podle těchto autorů podařilo státním orgánům i veřejnosti uchovat kladný vztah k Rusínům i Ukrajincům, i když někdy docházelo k vnitřním sporům uvnitř rusínské a ukrajinské menšiny. Z nejvýznamnějších kulturních prvků autoři poukazují na náboženství a jeho roli při používání rusínského jazyka - podle nich se ani řeckokatolická, ani pravoslavná církev nestaví k rusínštině jako jazyku bohoslužeb nijak vstřícně.

Prvky rusínské kultury na Slovensku - jak hmotné, tak i nehmotné - se zabývala v poválečném Československu celá řada folkloristů, etnografů i ukrajinistů (hlavně Růžena Šišková, Mykola Mušinka, Alexandr Mušinka, Andrej Kovač, Ivan Paňkevyč), jimž se podařilo zkompletovat, analyzovat i uchovat obrovské množství materiálu z rusínských oblastí Slovenska. Téměř všichni ve svých pracích považovali Rusíny za součást ukrajinského národa nebo používali etnonymum Ukrajinci-Rusíni. Ze současných autorů zaměrujících se na hlavní prvky rusínské kultury v současnosti lze uvést Annu Pliškovou, která 
dává důraz především na rusínský jazyk. Svými publikacemi se rovněž metodicky podílí na výuce rusínského jazyka.

\section{Počty Rusínů}

Slovensko je v současnosti státem, kde v celosvětovém měřítku žije nejvyšší počet Rusínů (podle oficiálních údajů z národních statistických úřadů). Zároveň se jedná o stát, kde nárůst počtu Rusínů v desetiletých obdobích mezi jednotlivými sčítáními vykazuje přírůstek desítek procent (v roce 2011 nárůst o $38 \%$ oproti roku 2001, v roce 2001 se jednalo o 40\% nárůst počtu osob rusínské národnosti oproti roku 1991).

V roce 2011 se při sčítání obyvatel na Slovensku přihlásilo k rusínské národnosti 33482 osob [Obyvatel'stvo podla národnosti 2011], na druhém místě bylo v roce 2011 Srbsko s 14246 Rusíny [Stanovništvo prema nacionalnoj pripadnosti 2011]. Jak ovšem tato čísla interpretovat? Vysoký nárůst počtu př́islušníků menšiny může být způsoben například vysokou porodností nebo masivním přistěhovalectvím. To ovšem případ slovenských Rusínů v žádném případě není. Jako další z možných vysvětlení se nabízí probíhající národní obrození slovenských Rusínů a posilování jejich etnického povědomí. Nazveme-li současnou situaci slovenských Rusínů jejich národnostním obrozením, pak je třeba vzápětí dodat, že se jedná o obrození spíše nesmělé, stále nepř́liš vyhraněné vůči většinovému okolí. Nejde rozhodně o zarputilý národní zápas, ale velmi postupné objevování vlastních etnických specifik.

Odpovědi rusínských respondentů jsou v naprostém rozporu s čísly při sčítání obyvatel - podle respondentů počet Rusínů výrazně klesá, mizí i používání rusínského jazyka. $\mathrm{Z}$ toho lze odvodit, že na Slovensku byl dříve podstatně vyšší počet Rusínů, kteří se ovšem k této národnosti nehlásili, protože nemohli nebo nechtěli.

Dimitrij Choma, respondent z východního Slovenska (2015), sdělil: „Počet Rusínů a Ukrajinců na východním Slovensku je dnes určitě daleko menší než např. v letech padesátých, šedesátých. Podle mého názoru se tak stalo především pod vlivem ekonomickým, tj. stykem obyvatelstva dříve uzavřených obcí, nebylo kam jezdit do práce, ty možnosti vnikly až po válce a k tomu autobusové spojení všech obcí, které před válkou neexistovalo. Po změnách režimu a ekonomické situace se venkov vylidňuje, není dost dětí a školy často zanikají“ [Fučíková 2016: 49].

Statistika počtu Rusínů na Ukrajině (k dispozici jsou pouze údaje z roku 2001, kdy proběhlo poslední sčítání obyvatel) může být ukázkou toho, že rozlišování etnických skupin na „národy“ nebo „etnografické skupiny“ může mít i politický základ. Nemožnost přihlásit se v socialistickém Československu k rusínské národnosti a ukrajinizace rusínského etnika po druhé světové válce má v současnosti analogii na Ukrajině. Ačkoli rusínské organizace jednoznačně hovoří o Rusínech jako o národu, ukrajinská vláda se tomuto termínu vehementně brání a při sčítání obyvatel neumožňuje přihlásit se k rusínskému národu (národnosti). Při sčítání obyvatel v roce 2001 se tedy na Ukrajině vyčleňovali v rámci ukrajinského národa Huculové (21 tis. osob), Rusíni (10,1 tis. osob), Lemkové (600 osob), Bojkové (130 osob), v neposlední řadě Litvinové, Pinčukové a Poleščukové.

To, že při sčítání obyvatel na Ukrajině dosáhl počet Rusínů pouhých 10100 obyvatel [Čislennost' i sostav naselenija Zakarpatskoj oblasti 2003], považují některé ukrajinské rusínské spolky za podvod při sčítání. Neoficiální počty Rusínů poskytují organizace 
zabývající se v celosvětovém měřítku mapováním národnostních menšin (např. Joshua Project) a uvádí počty Rusínů na Ukrajině úplně jiné - 513000 osob [Ruthenian in Ukraine 2016]. Další z významných organizací mapující používání jazyků (SIL International) uvádí počet Rusínů na Ukrajině ještě vyšší: 560000 osob [Rusyn 2016]. Ukrajina je dnes jedinou zemí s rusínským obyvatelstvem, která Rusíny neuznává jako samostatné etnikum.

Nejen ukrajinské statistiky Rusínům nepřály. Na příkladu slovenských Rusínů z 20. let 20. století je možné doložit, jak byly i československé statistiky v meziválečném období velmi nepřesné a tendenční. $V$ této době bylo možné se $\mathrm{k}$ rusínské národnosti přihlásit. Sčítací komisaři ovšem často definovali národnost Rusínů tak, že před ně položili knihu napsanou v azbuce. Pokud ji Rusín nedokázal přečíst (což bylo celkem časté kvůli předchozímu zákazu azbuky uherskou vládou), pak ho zapsali jako Slováka [Ševčenko 2011].

Z tohoto důvodu je třeba brát statistické počty slovenských Rusínů se značnou rezervou - přesnější údaje máme až z 90. let 20. století. Podle sčítání obyvatel v roce 2011 žil největší podíl Rusínů v okrese Medzilaborce (42,5\%). Na celém Slovensku bylo 36 obcí, v nichž se hlásilo 50 a více procent obyvatel s trvalým bydlištěm k rusínské národnosti.

Zatímco v dřívějších sčítáních byla na Slovensku rusínská národnost překrývána ukrajinskou, dnes je situace jiná - k ukrajinské národnosti se hlásí pětkrát méně osob než k rusínské. Přestože se v současnosti mohou na Slovensku všichni obyvatelé přrihlásit ke své národnosti bez jakéhokoli nátlaku a údaje slovenského statistického úřadu jsou považovány za nezkreslené, problémy s určením počtu Rusínů přetrvávají. Pro mnoho obyvatel stále není samozřejmé se při sčítání obyvatel přihlásit k rusínské národnosti, ačkoli se za Rusíny považují. Naopak někteří se při sčítání zapisují jako Rusíni, ale jedná se o zvyk a sami se za Rusíny př́liš nepovažují. Jako příklad mohou posloužit respondenti v rusínské obci Runina, kde se podle sčítání hlásí k rusínské národnosti přes 80 \% obyvatel. Část respondentů se za Rusíny považuje, a tak se i při sčítání zapisují. Někteří respondenti uváděli, že rusínská národnost je stejně fiktivní a vymyšlená jako ukrajinská národnost, ale přesto se při sčíání zapsali jako Rusíni. Jiní respondenti si nepamatovali, jakou národnost při sčítání uvedli - zda slovenskou, rusínskou nebo ukrajinskou. Další respondenti sdělovali, že ačkoli jsou Rusíni, při sčítání tuto národnost neuvedli, protože nechtějí podpořit představitele novodobého rusínského hnutí.

Rusíni byli v minulosti donuceni emigrovat, proto jich dodnes mnoho žije v USA, Kanadě, ale i např. v České republice a dalších okolních státech. Na Slovensku mají status národnostní menšiny a jejich jazyk, rusínština, je od roku 1999 zákonem uznaný jako jeden z 9 menšinových jazyků na Slovensku.

\section{Stručný historický přehled}

Vzhledem k tomu, že Rusíni nedisponovali státností, a navíc se dodnes vedou spory o jejich etnogenezi, je velmi obtížné sledovat i dějiny Rusínů na území dnešního Slovenska. Při historickém bádání se můžeme setkat s mnoha postupy, které často vychází z předpokladu, že každý národ má svoje dávné označení, jazyk, náboženství, zvyky a území. Zároveň dochází k používání stejného pojmu v naprosto odlišných disciplínách, jakými mohou být historie, lingvistika, genetika nebo etnologie. To, že nějaká skupina hovořila nebo hovoří stejným jazykem, vůbec nemusí znamenat, že má i shodné prvky v genografických testech, které se pokouší určit na genetickém základě blízkost různých populací. 
To, že u některé skupiny můžeme dokumentovat specifické zvyky a náboženské prvky, ještě vůbec nemusí znamenat, že zde najdeme i souvislost jazykovou.

Z toho, co o Rusínech v současnosti víme (nebo se domníváme, že víme), vyplývá, že netvořili národ v našem současném chápání, ale spíše se jednalo o mnohem méně sourodou skupinu. Tato nesourodost se v průběhu dějin ještě prohlubovala vytvářením státních hranic na území, kde žilo rusínské obyvatelstvo. O to, zda se jednalo skutečně o rusínské obyvatelstvo, se vedou už více než století mezi historiky spory - podle toho, co chtěl který historik dokázat, se tak mohlo jednat o obyvatelstvo ruské, slovenské, polské, ukrajinské, maloruské, slovanské, uherské a další.

Jako ukázka může posloužit dvojí pohled na obyvatele východního Slovenska z počátku 20. století: „Národnostní otázka území východoslovenského v starších časech není tak jasná, jakou se vidí. My máme na očích slovenské brýle, všechno vidíme slovenské. Ale jiní, neslovenští lidé, mohou mít jiný názor. Dovolávám se Vladimíra Hnatiuka, člověka seriozního, rozumného, učeného, který prošel téměř celé východoslovenské území. On na tomto území všude vidí Rusy (Rusíny), kde Slováci vidí Slováky, a proto nazývá toto území z hlediska původní národnosti sporným: území bylo od dávných dob ruské. Časem se zmenšovalo následkem odnárodňování Rusů ve prospěch Mad’arů a Slovákư “ [Czambel 1906: 22].

Doba příchodu rusínského obyvatelstva do oblasti východního Slovenska zůstává i dnes velmi sporná - může se jednat o příchod knížete Korijatoviče ve 14. století, ale slovanské obyvatelstvo zde mohlo žít i předtím. Právě 19. století bylo pro obyvatele na území dnešního Slovenska spojeno s obrovským vystěhovalectvím kvůli špatným hospodářským podmínkám. Statistické údaje z let 1869-1910 zaznamenaly na území dnešního Slovenska úbytek přes půl milionu osob. Kromě migrace v rámci Rakouska-Uherska se jednalo především o emigraci do USA [Jakešová 1988: 90-91]. Není možné určit přesný počet Rusínů, který opouštěl území dnešního Slovenska (ale i území jiných dnešních států, které byly součástí Uher), protože emigranti byli většinou evidováni jako občané Uher, a ne podle národnosti.

Rusíni v USA se sdružovali (a vyčleňovali vưči okolí) především na náboženském základě. Ačkoli neměli vlastní řeckokatolické kněze, vytvořili řeckokatolický spolek, ale žádali (v roce 1888) prešovského biskupa, aby jim poslal kněze. K tomu však byl nutný souhlas amerického biskupa. Ten zřejmě neměl ponětí o Užhorodské unii (zajištující církvi byzantského obřadu od 17. století plnou jednotu s Římem) a ženaté řeckokatolické kněze odmítl. Rusínský řeckokatolický kněz pak našel přijetí u ruské pravoslavné církve, přijal pravoslaví a zároveň se tento krok stal prvním rozkolem mezi americkými Rusíny, z nichž několik tisíc rovněž přestoupilo k pravoslaví. Řeckokatolickou správu vytvořil Vatikán až v roce 1916 - jednu pro Rusíny a další uherské řeckokatolíky v Pittsburgu a druhou pro Ukrajince v Philadelphii. V obou působili i řeckokatoličtí Slováci [Stolarik 2010: 56-84].

Ti Rusíni, kteří v Americe přijali pravoslaví (většina z 29000 rusínských konvertitů se stala členy ruské pravoslavné církve), zároveň horlivě přejímali i ruskou kulturu a opouštěli původní [Alter 1996: 3-21]. Přesto mnozí rusínští vystěhovalci udržovali do roku 1945 časté styky s Rusíny na Slovensku i v Podkarpatí.

Přes neutěšenou hospodářskou situaci začíná přibližně od 2. poloviny 19. století na území dnešního Slovenska jedna z důležitých etap rusínského národního obrození, iniciovaná revolučním rokem 1848, který urychlil proces rusínského sebeuvědomění. 
Rusíni ovšem na rozdíl od jiných slovanských a neslovanských národů během procesu svého národního obrození nevyřešili ani jednu základní otázku své národní existence: ani otázku národní identity, ani otázku kulturní orientace, ani otázku spisovného jazyka, dokonce ani samotnou otázku svého pojmenování [Plišková 2007: 9].

Po přičlenění území Podkarpatské Rusi k Československu v roce 1919 nastal dynamický kulturní, hospodářský a sociální rozvoj regionu. Zároveň ovšem pokračovalo tápání v odpovědi na otázku, kdo vlastně Rusíni jsou a kam patří. V meziválečném Československu se Rusínům na Slovensku nevěnovala přílišná pozornost, protože většina Rusínů žila především na Podkarpatské Rusi. Při sčítání obyvatel bývali Rusíni často započítáváni mezi Ukrajince a Rusy.

Etnonymum Rusín stále neměl jednoznačnou definici, ačkoli označení Rusíni se objevuje v mezinárodní smlouvě podepsané v Saint-Germain mezi Československem a vítěznými mocnostmi z roku 1919 [Sbírka zákonů Republiky Československé, 508/1921 Sb.]. V této smlouvě se Československo zavazuje poskytnout Rusínům územní a politickou autonomii - to se ovšem realizovalo až krátce před 2. světovou válkou. Další mezinárodní smlouva z Trianonu [Sbírka zákonů Republiky Československé, 102/1922 Sb.] určovala hranice mezi Mad’arskem a Československem a o Podkarpatské Rusi se zde hovoří jako o rusínském území státu československého.

Rusíni a Ukrajinci měli v rámci menšin žijících v Československu (na Slovensku) výrazná specifika. Kromě Podkarpatské Rusi se jejich původní osídlení omezovalo pouze na severovýchodní okresy Slovenska. Kromě řeckokatolického náboženství byla dalším specifikem Rusínů na Slovensku jejich sociální struktura, projevující se v absenci městského obyvatelstva a s tím spojeným minimálním zastoupením mezi ekonomickou a politickou elitou. Ani v jednom městě východního Slovenska netvořili Rusíni většinu. Teprve od 30. let 20. století začali Rusíni odcházet do měst a ještě výraznější zlom nastal v období komunismu.

To, že Rusíni žili na jednom místě, měli stejné náboženství a jednalo se především o vesnické obyvatelstvo, zpomalovalo modernizaci rusínské společnosti, ale na druhé straně tato situace chránila Rusíny před asimilací slovenského a mad’arského prostředí [Šoltés 2014].

Zatímco u jiných etnik je nejdůležitějším prvkem zabraňujícím asimilaci výrazná identita projevující se vyčleňováním vůči většině, u Rusínů se kromě náboženství žádný další prvek etnicity nijak výrazně neprojevoval. Slovenští Rusíni neměli jednotný jazyk, měli slabé historické povědomí o společném původu, neměli potřebu svoji národnostní identitu prezentovat navenek.

Od 20. let 20. století je patrné výrazné štěpení Rusínů v Československu podle politického zaměření. Politická orientace se tak u Rusínů stala velmi významnou součástí jejich identity - odvíjela se od ní preference při používání národního jazyka, preference náboženská (katolicismus versus pravoslaví) i preference etnická (Rusíni jako samostatný národ, jako součást ukrajinského národa, jako Slované vedení Ruskem).

Českoslovenští Rusíni se přikláněli k ukrajinskému nacionalismu především na Podkarpatské Rusi, zatímco na území Slovenska byly ukrajinské tendence mnohem slabší. Na základě rozpravy v československém parlamentu v roce 1931 uváděli poslanci z Podkarpatské Rusi, že místní obyvatelstvo je rozděleno na tři skupiny: na skupinu národní čili ukrajinskou, na skupinu velkoruskou čili moskevskou a na skupinu, která preferuje místní nářečí. 
Rusínský kulturní činitel Hijador Strypský (1875-1946) jednoznačně řadil Rusíny do západní Evropy: „Tak abyste věděli, že my Rusíni jsme západníci. My jsme spojení se Západem zeměpisně, historicky, hospodářsky a církevně, jsme spojení politicky i jazykově... Nechceme mít nic společného s rusko-tatarskou kulturou východní Moskvy, nás západníky nikdo nedokáže přeorientovat na východ, protože tato ruská kultura je nám cizí! Rusíni mají svůj originální jazyk, svébytnou kulturu a vlastní literaturu“ [Pop 2014].

Naproti tomu československý poslanec Husnaj, Rusín z Podkarpatska, dokazoval při svém projevu v parlamentu v roce 1931 ukrajinský původ Rusínů: „Pravdu z rusínských skupin má skupina ukrajinská, která se opírá o živou lidovou mluvu a o ochranu národopisného celku, jak to uznává učený svět a jak to uznala petrohradská akademie věd a česká akademie věd v Praze. Všichni museli uznat, že náš národ je částí ukrajinského národa, který žije v Haliči, na Bukovině a na Velké Ukrajině“ [Stenoprotokol 1931].

Československý ministr Klofáč požadoval v roce 1925 pro Rusíny podporu ruského školství, které je mělo uchránit před ukrajinským vlivem: „Bratři! My do rusínských škol nesmíme zavést ukrajinský jazyk. My musíme v těchto školách učit rusky, a to prostě proto, že Lvov je blízko a Moskva daleko a do Moskvy se naši Rusíni nikdy nedostanou!“ [Stenoprotokol 1931].

Ke konci 2. světové války došlo k oddělení slovenských Rusínů a Rusínů žijících na Podkarpatské Rusi. Východní Slovensko totiž na rozdíl od Podkarpatské Rusi nebylo př́ímo okupované vojsky Rudé armády a NKVD. Proto nebylo možné na východním Slovensku nastolit takový surový teror, jaký byl nastolen na Podkarpatské Rusi.

$\mathrm{V}$ poválečném období zároveň docházelo $\mathrm{k}$ agitaci sovětských úřadů, aby se Rusíni, kteří zůstali na Slovensku, přestěhovali do Sovětského svazu. Mělo dojít k výměně sovětských občanů - Čechů žijících od 19. století na Volyni za československé občany - Rusíny z východního Slovenska.

To popisuje Štefan Kruško ( $\left.{ }^{\star} 1940\right)$, jehož otec svůj domov na Slovensku opustil: „Sovětská vláda vyslala na východní Slovensko padesát politických agentů. Jejich úkolem bylo přesvědčit Slováky a Rusíny, aby vyměnili starou vlast za novou. Podařilo se jim přemluvit 12 tisíc našich občanů. Na svou agitaci si vybírali nejvíce zničené a válkou zbídačelé vesnice - Čertižné, Habura, Nižný Komárnik. Později mi otec vyprávěl, jak v naší vesnici slibovali komisaři při pálence parádní domy, plné stáje a tolik rolí, kolik stačí obdělat. Uvěřil i můj otec... Nikdo ale lidem neřekl, že po překročení hranic okamžitě přijdou o československé státní občanství a stanou se občany SSSR“ [Kruško 2013].

Rusíni, kteří uvěřili sovětské agitaci o bohatých hospodářstvích po volyňských Češích, byli krutě zklamáni - po jejich prŕijezdu byla totiž většina nemovitostí obsazena. Kdo se pokusil o návrat do Československa, končil ve vězení nebo v gulagu. První organizovaný návrat vysídlených osob do Československa proběhl až po Stalinově smrti v roce 1953. Návrat se podařil $70 \%$ těchto osob. Podmínkou byla pozvánka od blízkých prríbuzných z vlasti k trvalému pobytu v Československu [Kruško 2013].

Od roku 1945 se stávalo ukrajinské obyvatelstvo na území dnešního Slovenska privilegované a počítalo se s tím, že bude vystupovat jako prodloužená ruka Moskvy. Rusíni byli v tomto období považováni jednoznačně za Ukrajince a rusínská národnost byla označovaná jako výplod „mad’arizace“ [Bobák 2000].

Překážkou ukrajinizace československých Rusínů byla především řeckokatolická církev, která byla v roce 1950 státním zásahem zrušena a spojena s pravoslavnou církví. 
Uvolnění poměrů v Československu kolem roku 1968 přineslo pozitiva i Rusínům. Kromě obnovy řeckokatolické církve (kterou někteří pravoslavní Rusíni jako pozitivum př́liš nevnímali), se rusínská národnost objevuje jako součást československé ústavy. Ústavní zákon z roku 1968 o postavení národností v Československé socialistické republice [Sbírka zákonů ČSSR, 144/1968 Sb.] zmiňuje mad’arskou, německou, polskou a ukrajinskou (rusínskou) národnost a zároveň ruši článek ústavy z roku 1960, jež v Československu uznávala pouze národnost mad’arskou, ukrajinskou a polskou. Rusínská národnost v závorce vždy společně s národností ukrajinskou je pak uváděna ve všech československých právních předpisech až do roku 1989 (a ještě později, dokud nedošlo i ve vztahu k Rusínům ke změnám v novém právním řádu).

Po roce 1989 nastala obroda rusínské národnostní menšiny, přičemž byla uznána jako zvláštní národnost s možností přihlásit se $\mathrm{k}$ př́íslušnosti k ní ve sčítání obyvatelstva. I po rozpadu Československa pokračovala vstřícná politika slovenské vlády vưči Rusínům. Kromě finanční podpory, kterou dostávají všechny uznané menšiny na Slovensku, získali Rusíni od roku 1997 i vlastní školství v rusínském jazyce. Je ovšem paradoxem, že o školství, o něž usilovali před více než sto lety rusínští obrozenci, není v současnosti př́lišný zájem a rusínské školy na Slovensku se potýkají s obavami o svou budoucnost.

Devadesátá léta ovšem pro Rusíny východního Slovenska znamenala rovněž snížení životní úrovně. Slovenské okresy s nejvyšším počtem Rusínů byly v produkčních ukazatelích i v životní úrovni v celoslovenském srovnání téměř vždy podprůměrné. Mezi Ukrajinci a Rusíny na Slovensku byl nadprůměrný podíl členů komunistické strany, ale protože se rusínští komunističtí představitelé dokázali angažovat v rusínských oblastech při zvyšování životní úrovně obcí, byli okolím vnímáni spíše pozitivně. V 90 . letech 20 . století, kdy docházelo k obrovské proměně ekonomického systému, došlo k ještě většímu zaostávání východního Slovenska. Rusínské (a ukrajinské) ekonomicky aktivní obyvatelstvo mělo nadprůměrný podíl v zaměstnání v zemědělství, ale i ve školství a zdravotnictví, zatímco značně podprůměrný podíl v průmyslu, stavebnictví a obchodu. Rusínské obyvatelstvo už v této době nepatřilo mezi zaostalé - podíl osob s vysokoškolským vzděláním byl vyšší než celoslovenský průměr [Gajdoš - Konečný 2005: 57 an.].

\section{Hlavní prvky etnické identity slovenských Rusínů}

Etnická identita slovenských Rusínů nebyla nikdy př́liš silně ukotvena a spíše se projevovala jako určité lavírování mezi identitami okolních etnik. Sami Rusíni často uvádí, že je pro ně obtížné definovat, co je jako etnickou skupinu spojuje. Téměř všichni ale nějakým způsobem odkazují na náboženskou tradici.

\section{Náboženství Rusínů}

Z náboženského hlediska byli Rusíni od Užhorodské unie ${ }^{1}$ roku 1646 v podstatě až do roku 1950 etnikem vyznávajícím jedinou, a to řeckokatolickou církev. Teprve sekularizace společnosti a pronikání pravoslaví po první a zejména po druhé světové válce narušilo

1 Dohoda mezi církví byzantského obřadu v Mukačevu a římskokatolickou církví o plném církevním společenství. 
původní homogenní náboženskou strukturu. Prostřednictvím př́slušnosti k řeckokatolické církvi se nejčastěji projevovalo chápání rusínské etnicity - to bylo patrné už během rusínského národního obrození $v$ 19. století, kdy se objevovaly problémy s jednoznačným vymezením rusínské etnicity v Uhrách.

Řeckokatolická církev na území dnešního Slovenska byla úzce propojena s Podkarpatskou Rusí - první biskupství v Prešově, zřízené v roce 1815, vzniklo vynětím z mukačevské eparchie na území dnešní Ukrajiny a bylo ze strany Říma označeno jako rusínské (ruténské). Oblast stř̌edního a jižního Zemplína (dnešní východní Slovensko) však zůstala pod správou mukačevského biskupa (de facto do r. 1939, právně se však celá záležitost dořešila až vznikem Košického exarchátu v r. 1997).

Zlomovým rokem pro řeckokatolické Rusíny (a všechny ostatní řeckokatolíky) na Slovensku byl rok 1950, kdy byla nařízením československé vlády zrušena řeckokatolická církev a násilně připojena $\mathrm{k}$ pravoslavné církvi. Pravoslavná církev na území Československa ovšem $\mathrm{v}$ předválečném období trpěla roztřištěnou orientací na Srbsko a Moskvu. Několik pravoslavných farností vytvořili i ruští emigranti prchající do Československa z Ruska po roce 1918. Početně byla v Československu pravoslavná církev výrazně slabší než řeckokatolická - v roce 1950 se k ní hlásilo 57500 věřících oproti 305654 řeckokatolíkům [Vévoda 2000: 317]. Po komunistickém převratu v Československu v roce 1948 však došlo $\mathrm{k}$ všestrannému politickému preferování pravoslavné církve (spadající pod moskevský patriarchát), jejižz mnozí členové i duchovní otevřeně spolupracovali s komunistickou stranou. V květnu 1950 byl zinscenován sobor, jehož účastníci jednomyslně rozhodli o zrušení řeckokatolické církve v Československu a jejím připojení k pravoslavné církvi.

Většina duchovních i věřících ovšem $\mathrm{k}$ pravoslaví nepřistoupila a bud' navštěvovali bohoslužby a přijímali svátosti tajně, nebo v rámci ř́mskokatolické církve. Zároveň docházelo $\mathrm{k}$ pronásledování těch církevních představitelů i věřících, kteří začleňování do pravoslaví odmítali. Ke změnám došlo až v souvislosti s politickým uvolněním v Československu v roce 1968, kdy došlo k obnovení řeckokatolické církve.

Tato obnova ovšem odstartovala celou řadu sporů řeckokatolíků s pravoslavnými v majetkových záležitostech týkajících se kostelů a dalších nemovitostí. Pravoslavná církev byla i nadále spojována se Sovětským svazem. Běžným se stalo osočování, že je bolševická a slouží komunismu. Spory vedly mnohokrát k ničení majetku kostelů, znesvěcování bohoslužebných předmětů, násilnému vyhánění kněží z far [Lupčo 2013: 247-264].

Zajímavá byla ovšem i argumentace obou stran - podle řeckokatolíků měli pravoslavní odevzdat veškerý majetek, který od nich získali po roce 1950. Pravoslavní argumentovali tím, že řeckokatolíci vytvořením unie s Římem a opuštěním pravoslaví v 17. století rovněž převzali veškerý pravoslavný majetek, který nevraceli. $\mathrm{V}$ těchto náboženských sporech často proti sobě stáli Rusíni i z jedné vesnice.

Respondent z Runiny (v r. 2015) takto popisuje tehdejší situaci: „Kolem roku 1968 to bylo strašné, na některých rusínských vesnicích se lidé i poprali, jednomu faráři utopili dítě ve vápně. To ovšem pak není náboženství, to je šílenost. V 70. a 80. letech bylo křestanství pronásledované a zase naopak na některých místech se lidé dokázali domluvit. Řeckokatolíci si půjčovali kostely s pravoslavnými a řeckokatolíci někdy chodili na pravoslavné mše a naopak."

Náboženství spojovalo slovenské Rusíny s Rusíny v emigraci. V obci Runina je pravoslavný kostel, který si sami postavili místní obyvatelé. Zvony do zvonice byly zakoupeny ze 
sbírky občanů obce, kteří se vystěhovali za prací do USA. Rusínští vystěhovalci se na jiných místech podíleli finanční pomocí na obnově křižů nebo kaplí. Tyto sakrální památky se stávají důležitým prvkem rusínské pospolitosti i jako „místa paměti“, díky nimž přetrvává vědomí, které by jinak mohlo být zapomenuto [Klepetko 2014: 64-79].

V současnosti se Rusíni hlásí k řeckokatolické či pravoslavné církvi, výjimečně i k jiným nebo žádným církvím. Nejčastějším faktorem ovlivňujícím příslušnost jedince k určité církvi je rodinná tradice. Ta je také velmi patrná v případě slavení náboženských svátků a rodinné obřadnosti. Náboženství utváří identitu Rusínů nejsilněji, avšak nikoliv samostatně, nýbrž společně s dalšími aspekty.

Pro řeckokatolického respondenta je náboženská příslušnost součástí rodové tradice: „Jsem řeckokatolického vyznání, protože jsem se narodil do rodiny řeckokatolíků. Prakticky celá rodina po otcově i mámině straně jsou řeckokatolíci. Musel bych jít hodně generací dozadu, abych našel někoho v rodině, kdo nebyl u řeckokatolíků.“ Podobně se k otázce vyznání vyjadřoval pravoslavný respondent: „Protože jsem se narodil jako pravoslavný, zemřu také jako pravoslavný." Respondentka ze smíšené rodiny běžně navštěvuje římskokatolické i řeckokatolické bohoslužby: „Pocházím ze smíšené rodiny, kde otec je řeckokatolík a máma římskokatolička, pokřtěná jsem jako římskokatolička, ale společně celá rodina navštěvujeme římskokatolické i řeckokatolické bohoslužby.“

Podle řeckokatolického faráře Martina Tkačina (rozhovor s respondentem v roce 2016) je základem rusínské identity právě náboženství, od něhož se odvíjejí další části rusínské kultury: „Pokud se nebude uchovávat jazyk a kultura, tak rusínská menšina zanikne. Proto máme všechna kázání v rusínštině a liturgii slavíme ve staroslovanštině. Některé způsoby pomoci pro rozvoj rusínské kultury se mohou naopak stát velkou př́ičinou zmatku vlastní identity. Aktuálním př́kladem je Evropská unie s její podporou folklóru a rusínských tradic. Ve skutečnosti jde ale jen o to, že chtějí vidět lidi tancující v krojích u opravených kostelíků, jak pijí a jedí něco, čemu se ř́ká tradiční a nejlépe i bio. Nikdo ale nechce vidět, co je spjaté s náboženstvím. A to je ta největší chyba. Vždyt právě prostřednictvím náboženství se předával jazyk Rusínů, vytvářel se vztah k vlastní řeči a předávalo se etnické povědomí.“

Téměř všichni respondenti považují náboženství za nejsilnější prvek rusínské identity. Přestože bývá označováno jako faktor „odlišující Rusíny od jejich polských, slovenských a ukrajinských sousedư “ [Shea 1999], neplatí to zcela. Faktem je, že od náboženství se skutečně odvíjí celá řada dalších prvků rusínské kultury - například rusínské muzeum v Čirči je muzeem národním, ale strukturou exponátů především církevním.

Na druhou stranu je patrné, že mnoho (především slovenských a ukrajinských) sousedů Rusínů vyznává náboženství stejné a sami Rusíni jsou navzájem rozdělení mezi řeckokatolíky a pravoslavné. I unikátní církevní zpěvy prostopenije nejsou specifikou jen rusínských bohoslužeb, ale i slovenských nebo ukrajinských.

Důležitost náboženství pro Rusíny je možné ilustrovat na příkladu Rusínů žijících v Čechách, kteří se nediferencují podle prŕslušnosti k řeckokatolické nebo pravoslavné církvi. V Praze i rusínští pravoslavní věřící navštěvují s ostatními Rusíny řeckokatolické bohoslužby v chrámu sv. Klimenta, společně světí velikonoční jídla a spojuje je také to, že dávají přednost staroslovanské liturgii. Pokud se řeckokatolíci nemohou účastnit řeckokatolické liturgie, navštěvují spíše římskokatolické bohoslužby. Slovenští Rusíni hlásící se k pravoslaví nevyhledávají pravoslavné bohoslužby, nebot’ „tam sú Rusi, Ukrajinci a iní“ [Sulitka 2016: 451-472]. 


\section{Jazyk jako prvek rusínské identity}

Používání vlastního jazyka bývá velmi často jedním z hlavních pilíruo etnické identity. Jazyk může velmi dobře posloužit jako vstupenka (nebo závora) mezi členy určité skupiny - řeč se specifickým přízvukem ihned odhaluje „ty ostatni“ a vymezuje je vưči „nám“. Jazyk ovšem může mít i další funkci: může se jednat o velmi oceňovaný odkaz předků. I v těch př́ípadech, kdy se ke každodennímu užití používá jazyk okolní majority, existuje mezi členy skupiny silné povědomí vycházející ze společného jazyka. Případ slovenských Rusínů je ale do značné míry odlišný.

Statistika sčítání obyvatel na Slovensku totiž poměrně přesvědčivě ukazuje, že vlastní jazyk Rusínů rozhodně není hlavním prvkem, skrze nějž se buduje jejich etnická identita. Při sčítání v roce 2011 totiž uvedlo rusínštinu jako rodný jazyk o dvě třetiny více osob (55 469), než kolik se jich přihlásilo k rusínské národnosti (33 482). Z těch, kdo deklarují rusínštinu jako rodný jazyk, se jich pouze 54 \% hásí k rusínské národnosti a celých $41 \%$ k národnosti slovenské [Obyvatel'stvo podla pohlavia a národnosti 2011].

Jazyková situace slovenských Rusínů je tak do značné míry unikátní, protože mnohem častější situace u národnostních menšin po celém světě je zcela opačná. Počet mluvčích př́slušného jazyka bývá téměř vždy nižší než počet osob daného etnika.

Přesto podle respondentů slovenští Rusíni v současnosti ve velké míře opouští rusínštinu a přechází na slovenštinu. To popisuje respondent z východního Slovenska: „Asimilace Rusínů je nejvíce patrná v jazykové oblasti. Znám mnoho rusínských rodin, které své děti nenaučily rodné řeči. Jako kdyby se za to styděli a zapomněli na to, kdo byl jejich otec, matka, děda a babička, kde se narodili a kdo byl jejich bratr a sestra" [Fučíková 2016: 50].

Jazyková situace rusínských oblastí byla velmi pestrá a ovlivněná jazykem okolních etnik. Na území dnešního Slovenska se jednalo především o vliv mad’arštiny, slovenštiny, polštiny, ukrajinštiny, ale jazyk ovlivňovali i Němci, Židé a občas i další národy. Toto mísení jazykových vlivů můžeme pozorovat na Uglianském rukopisu s evangelijní tematikou, pocházejícím ze 17. století z Podkarpatské Rusi. Jazykové vědomí autorů se výrazně liší ve frekvenci používání nářečních prvků a výpůjček z mad’arštiny. Nejednotnost jazyka byla patrná na tom, že někteří i v písemném projevu používali místní dialekt, jiní jazyk vycházející z církevní slovanštiny (někteří i z latiny), s výpůjčkami z mad’arštiny, slovenštiny, polštiny, ruštiny a ukrajinštiny [Homzová 2010].

Z jazykového hlediska prosazovali od 2. poloviny 19. století rusínští řeckokatoličtí kněží, kteří stáli v čele národního obrození, především používání církevní slovanštiny. Podobného názoru byla i církevní hierarchie. Církevním liturgickým jazykem byla sice církevní slovanština lvovské redakce, ale pastýřské listy, matriční a další farní agenda se vedly v tzv. jazičii (směs církevní slovanštiny a rusínských nářečí) [Švagrovský - Ondrejovič 2004: 129-150].

Světští obrozenci preferovali ruštinu - především vlivem panslavismu, který získal na síle po revolučním roce 1848 - ale většině samotných Rusínů byly mnohem bližší místní dialekty.

Ještě před vznikem Československa se řešila otázka jazyka Rusínů. V případě Podkarpatí byla situace relativně klidnější, protože rusínské obyvatelstvo (i přes velké množství dialektů) tvořilo většinu. I tak vyvstávaly problémy s vymezením se vưči maloruštině/ 
ukrajinštině. Na území dnešního Slovenska však byla situace složitější. Pestrost různých dialektů umožňovala historikům i politikům poměrně volně vytvářet ideje o př́slušnosti místního obyvatelstva k Polákům, Mad’arům, Rusům, Ukrajincům, Slovákům, Rusínům.

Jazyková otázka zůstala nevyřešená i po vzniku Československé republiky. Na Slovensku přetrvávaly slovakizační tendence, které se projevovaly například při sčítání obyvatel, ale v některých obcích byl rusínský jazyk vytlačován slovenštinou ještě před vznikem Československa. To popisuje M. Sčavnicky ( ${ }^{*} 1833$, vyprávěl v roce 1904): „Když mi bylo dvanáct, tak v Sobranci všichni ,hutorili po ruski‘ (mluvili rusínsky). Staří ještě celkem umí mluvit rusky, ale mladí už jenom slovensky“ [Kontratovič 1924: 4].

Prešovské rusínské noviny Russkoje slovo ukazovaly na začátku 20. století spor mezi rusínským a slovenským pohledem na Rusíny žijící na východním Slovensku. Podle slovenského nacionalistického pohledu měli být Slováci původním obyvatelstvem dané oblasti, kteří tam žili již v 1 . století před Kristem, a Rusíni (Rusi) jsou obyvatelstvem nepůvodním. Proti těmto historickým manipulacím se stavěl pohled rusínský, podle kterého i obyvatelé východního Slovenska považovaní za Slováky si jazykově mnohem více rozumí s Rusíny než se Slováky. Rusíni v Šariši i Zemplíně mohou ukázat i zápisy ze 17. století, kde je patrný jejich rusínský původ [Kontratovič 1924: 3].

Přestože se československá vláda zavázala k ochraně národnostních menšin a umožnění vzdělávání v menšinových školách, u Rusínů nastal problém se spisovným jazykem. Za vyučovací jazyk byl sice na Podkarpatské Rusi vyhlášen místní jazyk, ale ten nemohl být přesně specifikovaný, protože nedošlo k jeho kodifikaci.

V souvislosti s kodifikací rusínského jazyka platí stejný postup jako u jiných jazyků. Kodifikace představuje zachycení určité jazykové normy a částečně i její předpis. Nejprve dochází k ustavování normy mezi mluvčími při používání jazykových prostředků a až poté v konečné fázi nastupuje kodifikace. Použivání rusínštiny jako lidové mluvy ovšem ovlivňovalo přizpůsobování se prestižním jazykům (církevní slovanština, mad’arština, ruština). Vytváření standardů bylo ovlivněné i tím, že neexistovalo př́liš mnoho literatury psané v rusínštině. Situace slovenských Rusínů byla v meziválečném období značně odlišná od Rusínů na Podkarpatské Rusi, přestože obě skupiny žily ve stejném státě. Zatímco na Podkarpatské Rusi se část rusínské inteligence jazykově silně inspirovala ukrajinštinou, na Slovensku proukrajinské tendence nikdy nedosáhly takové síly. Ve školách se tedy vyučovalo jazyčie jako směs církevní slovanštiny, ruštiny a místního rusínského hovorového jazyka [Kushko 2007: 111-132].

Po skončení druhé světové války došlo ke zpřetrhání vazeb slovenských Rusínů na Podkarpatí, které se stalo součástí SSSR. Obyvatelstvo severovýchodního Slovenska v běžné komunikaci téměř výlučně používalo místní dialekt. Část inteligence používala v oficiálním a písemném styku ruštinu, ale spisovný ukrajinský jazyk na Slovensku vlastně nikdo neovládal. Širší použití mělo jazyčie, které bylo do určité míry kodifikované, ovšem k jeho všeobecnému rozšíření nedošlo [Gajdoš - Konečný 1994: 98-99].

Uvolnění poměrů v Československu po roce 1989 přineslo i všeobecné angažování Rusínů. Proto se toto období někdy označuje jako třetí rusínské obrození. V rámci obrody došlo i na jazyk a 27. ledna 1995 byla v Bratislavě slavnostně vyhlášena kodifikace rusínského jazyka na Slovensku. Rusínský jazyk je zaveden do vzdělávacího systému Slovenské republiky od školního roku 1997/1998 včetně používání rusínských učebnic od 
1. do 9. tř́́dy. Na Slovensku působily v roce 2013 dvě mateřské školy, jedna s výchovným jazykem rusínským a jedna s výchovným slovenským a rusínským jazykem. Stejně dvě základní školy vyučují žáky v rusínském jazyce a jedna základní škola s vyučovacím jazykem slovenským a rusínským. Jako jediné vysokoškolské pracoviště na Slovensku zajištuje př́pravu učitelů rusínského jazyka Ústav rusínského jazyka a kultury v Prešově. Zaměřuje se na čtyři oblasti: vědecko-výzkumnou a vývojovou oblast normalizace rusínského spisovného jazyka, pedagogicko-výchovnou, publikační a dokumentační činnost [Rusínska národnostná menšina 2016].

Přestože dochází k zakládání rusínských škol, jejich další fungování se jeví jako velmi problematické. Na slovenských vesnicích mají kvůli snižujícímu se počtu žákủ velký problém $\mathrm{s}$ přežitím i slovenské školy. Na obecné problémy se školstvím v malých obcích poukazuje i respondentka ze Svidníku (rozhovor v r. 2015): „Postavení Rusínů na Slovensku je velmi okrajové. Na vesnicích zaniká školství jako celek, nemluvě o národnostním školství, které začalo zanikat již od roku 1996, a nebýt aktivit občanského sdružení Kolébka, už by se rusínský jazyk vůbec nikde neučil." Někteří rodiče mají obavu posílat děti do rusínských škol, aby na vyšším stupni zvládaly výuku ve slovenštině.

\section{Specifika rusínské kuchyně}

Jídlo je velice silným nástrojem, kterým lze projevovat vlastní, nejen etnickou identitu. Jídlem lze vyjádřit velké množství symbolů - náboženských, etnických, společenských, mnoho kultur se prostřednictvím pravidel a výběru jídla vymezuje vủči kulturám jiným.

Mnozí respondenti, kteří si jsou pouze vědomi svého rusínského původu, nepoužívají rusínský jazyk ani nedodržují rusínské tradice, přesto vaří rusínská jídla. Tato jídla, i když se původně vařila ve všední dny, pak mají sváteční charakter.

Respondentka ze Sniny, 23 let, uvedla (2015): „Naše rodina byla původně rusínská, dědeček ještě žil v rusínské vesnici. Když ale kvưli přehradě vesnice zbořili, přestěhoval se do města a moji rodiče i já žijeme ve Snině. Co nám zůstalo z rusínské tradice, to jsou jídla. Když je nějaký svátek, tak připravujeme nějaká rusínská jídla a na Vánoce musíme mít vždycky pirohy, bez toho by to nebyly Vánoce."

Rusínská kuchyně je typická velkým zastoupením bezmasých jídel, z nichž jsou na prvním místě brambory a zelí. Za typicky rusínský pokrm se považují vařené tatarčané pirohy (z pohankové, pšeničné mouky, vajec, soli a vody) s náplní ze sýra, zelí, brambor, hub. Další rozšiřenou specialitou je mačanka. Jde o polévku ze zápražky na slanině se štávou z kysaného zelí. Připravuje se s klobásou nebo houbami a jí se s chlebem, který se do polévky máčí - proto mačanka. Oblíbené byly i kaše (kuljaša, čyr), připravované z ovesné, ječmenné, kukuřičné a pohankové mouky. Mimo postní období se polévaly na slanině osmaženou cibulkou a zapíjely mlékem či polévkou. Ve slovenských restauracích se objevují rusínská jídla, i když rusínská kuchyně ovlivnila slovenskou pouze v místech, kde Rusíni žijí.

Na druhou stranu na Slovensku není žádné gastronomické zařízení, které by se specializovalo jen na rusínskou tradiční kuchyni. V nabídkách restaurací se rusínská jídla prezentují jako regionální speciality rusínských oblastí - Zemplín, Šariš a Spiš na území Prešovského a Košického kraje. Ze 4000 slovenských restaurací, jež mají na internetu jídelní lístek, se objevila mačanka ve 192, tatarčané pirohy v 44 a kuljaša jen ve dvou restauracích [Rehák 2013: 40-41]. 
Stravování je i v současnosti silně ovlivněno řeckokatolickými i pravoslavnými svátky, které se promítají do typických jídel, jejich každodenního i svátečního života. K určitým svátkům patřila a dodnes patří typická jídla - ta ovšem nemusela být vždy nutně výsadou Rusínů, ale mohla se objevovat i u okolního obyvatelstva.

Příkladem může být velikonoční jídlo, které se nosilo (a dodnes nosí) na velikonoční neděli do kostela na posvěcení. S drobnými obměnami je toto jídlo velmi podobné nejen na Slovensku, ale i mezi Slováky žijícími jako menšina v jiných státech. V madarské Baňačce se jedná o více jídel se symbolikou velikonočních událostí: koláč a šunka představovaly Ježíšovo tělo, klobása bič, kterým bičovali Ježíše, vajíčka kameny, kterými kamenovali Krista, víno představovalo krev, hrudka představovala žluč, kterou rozmíchali ve víně a dali Ježíšovi pít, a plnka (nádivka) znamenala houbu [Kokaisl 2014: 146]. Na východním Slovensku se připravuje takzvaný sirek, což je specialita z mléka a vajíček, ale nelze říci, že se jedná o rusínské specifikum, protože se sirek připravuje i v rodinách, jež se k rusínské národnosti nehlásí.

V mnoha východoslovenských vesnicích se Rusíni odlišují od slovenského obyvatelstva př́sností postu v souvislosti s hlavními svátky církevního roku - Velikonocemi a Vánocemi a striktním odmítáním určitých př́ísad do jídel v postní době (mléko, vejce...).

\section{Slavení svátků}

Rusínské tradice zaznamenávala od rusínského obrození v 19. století až do nedávné minulosti celá řada etnografů a o výsledky jejich práce je dodnes mezi Rusíny velký zájem. Slavení rusínských svátků vychází jak ze svátků závislých na ročních obdobích, tak i ze svátků během církevního roku - právě svátky spojené s liturgickým kalendářem nejvíce odolávají změnám a brání se zániku.

Faktem totiž je, že celá řada zvyků už v současnosti není živá, ale ukazuje se jako umělý folklór. Na druhou stranu v některých případech dochází k přejímání folklorních prvků i do rodinné obřadnosti - někteří Rusíni po zhlédnutí muzejních exponátů nebo folklorních představení s rusínskými zvyky chtějí tyto zvyky obnovovat i ve své rodině.

Změny ve slavení svátků ovšem nejsou jen záležitostí poslední doby, ale jedná se o průběžný proces. Ve 20. století došlo k postupnému zániku mnoha svátků - starobylý svátek spasa jako svátek úrody přestal existovat již po první světové válce. Velice oblíbená slavnost dožínek (obžinky) zanikla po druhé světové válce, ale byla obnovena po kolektivizaci. Po roce 2000 se tento zvyk částečně pozměnil a mezi některými vesnicemi na slovenské a polské straně hranice se uskutečňuje výměna dožínkových věnců. Jako další př́íklad je možné uvést slavení Dušiček 2 . listopadu, které dříve v rusínských vesnicích neměly vůbec žádnou tradici. Od 60. do 90. let 20. století docházelo k přejímání tohoto svátku od slovenských římských katolíků a nyní je všeobecně rozšiřen. Zároveň se tento svátek stal často jedinou příležitostí k setkání širšího příbuzenstva [Šišková - Mušinka - Mušinka 2005: 63-65].

Přestože řeckokatolický obřad má podle juliánského kalendáře stejné svátky jako pravoslavný, dochází u řeckokatolických Rusínů ke změnám, protože stále více používají gregoriánský kalendář. Do 70. let 20. století používali Rusíni juliánský kalendář a slavili Vánoce stejně jako pravoslavní 6 . ledna. V současnosti většina řeckokatolických Rusínů slaví Vánoce 24. prosince, ale část 6. ledna spolu s pravoslavnými Rusíny. Přesto velmi záleží na konkrétní rodině, jak si určí, kdy chce Vánoce slavit. Podle respondentů nelze 
jednoznačně uvést, kdy Rusíni Vánoce slaví. Někteří respondenti uváděli, že slaví Vánoce dvakrát - prosincové spíše v rodinném kruhu, lednové pak s přáteli.

Všechny svátky sice mohou být označené jako typické pro slovenské Rusíny, ale nejedná se o jejich slavení ve smyslu jsme Rusíni, a proto tyto svátky slavíme. Mnohem více se jedná o vnímání tradice slavení těchto svátků ve spojení s liturgickým kalendářem a způsob slavení včetně typických zvyků bývá velmi podobný nebo totožný u Rusínů i Slováků.

\section{Shrnutí}

Proměny rusínské etnické identity na území dnešního Slovenska: Ukazuje se, že rusínská etnická identita byla v minulosti velmi málo vyhraněná. Slovenští Rusíni si poměrně dlouhou dobu uchovávali specifický způsob života, který formoval jejich etnickou identitu a byl odvozován především z náboženství.

Rusínské národní obrození v 19. století sice vedlo $\mathrm{k}$ většímu zájmu o rusínské kulturní prvky, ale nepřineslo to, čeho dosahovaly ostatní malé národy. Nedošlo k jednoznačnému určení národní identity, nebyl kodifikován spisovný jazyk, a dokonce zůstalo velmi sporné i pojmenování Rusínů. Nevyhraněná a nevýrazná identita Rusínů přetrvávala i ve 20. století. Přesto si obyvatelstvo východního Slovenska (i přes nejrůzněǰ̌í etnonyma zaváděná zvenčí) uchovávalo povědomí určité specifičnosti a odlišnosti od okolí. V současnosti napomáhají prohlubování vlastního etnického vědomí rusínské spolky. Přestože se fakticky počet Rusínů (těch, kdo sdílejí společné kulturní prvky bez ohledu na to, jakým etnonymem se označují) zmenšuje, statisticky dochází k jejich nárůstu. Je to dáno tím, že se stále více lidí hlásí př̀ sčíání $\mathrm{k}$ rusínské národnosti.

Faktory působící na proměnu identity: $Z$ důležitých faktorů, které způsobovaly proměnu rusínské identity, patří bezesporu na první místo státní zásahy. Ty si dokázaly najít cestu i do odlehlých rusínských vesnic a například formou nařízení o vyučovacím jazyce působily na rozvoj (nebo útlum) používání rusínštiny nebo spíše širokého spektra jejích dialektů. Státní zásahy přinesly v mnoha ohledech i násilnou ukrajinizaci spojenou s likvidací pro Rusíny tak typické řeckokatolické církve. Ne vždy přinášely státní zásahy to, co od nich státní moc očekávala - např́klad likvidace řeckokatolické církve často vedla $k$ většímu semknutí rusínské komunity. Na druhou stranu tyto zásahy přinášely štěpení rusínské komunity na mnohdy velmi nesnášenlivé tábory. Současné státní zásahy přinášejí zákonný status rusínského národa i jazyka i podporu vyučování v rusínském jazyce.

Druhým, rovněž poměrně důležitým prvkem jsou geografické podmínky. Izolovanost rusínských vesnic a zanedbatelný podíl Rusínů žijících ve městech do značné míry bránil jejich asimilaci a umožňoval zakonzervování mnoha kulturních specifik jejich života. Se zlepšováním dopravní dostupnosti jsou obyvatelé rusínských vesnic mnohem více vystaveni asimilačním tlakům a zároveň výzvám hledat zaměstnání i nový domov mimo oblast kompaktního rusínského osídlení.

S tím úzce souvisí probíhající modernizace a urbanizace, která neovlivňuje jen Rusíny. $\mathrm{Z}$ mnoha důvodů dochází $\mathrm{k}$ vylidňování dříve národnostně velmi homogenních vesnic a odchodu obyvatel do měst. Na mnoha vesnicích začínají mizet školy a rychle se snižuje i občanská vybavenost (obchody, pohostinství). Někteří Rusíni po odchodu do velkých měst ovšem svoji etnickou identitu neztrácí, ale projevují ji mnoha způsoby aktivitou v národnostních spolcích. 
Hlavní kulturní prvky utvářející v minulosti a v současnosti etnicitu rusínského obyvatelstva na Slovensku a jejich změny: Etnicitu rusínského obyvatelstva nejvíce vytvářelo křestanské náboženství s východním obřadem, které v největší míře formovalo i další rusínské specifické kulturní prvky: používání jazyka, slavení svátků, dodržování postních předpisů spojených velmi často i s typickou kuchyní. Podobně jako u jiných národů, které svou etnickou vyhraněnost staví na specifickém náboženství (Irové a Angličané, Srbové a Chorvati...), je i v př́ípadě Rusínů přesnější poukazovat spíše na náboženskou tradici než na samotnou př́íslušnost k určité církvi. To je vidět na současných Rusínech, kteří mohou být i bez vyznání, a přesto svou rusínskou identitu bez náboženských tradic často nedokážou definovat. Další prŕíklad mohou poskytnout pravoslavní Rusíni žijící v diaspoře, i když mají možnost navštěvovat pravoslavné bohoslužby (které většinou navštěvují Rusové a Ukrajinci), upřednostňují bohoslužby katolické (s větším zastoupením Rusínů).

Současnost přináší i větší důraz Rusínů na používání rusínského jazyka. Mnozí Rusíni začínají považovat za kritérium plnohodnotného národa „trojjedinost“ v propojenosti tří prvků - národa, území a vlastního jazyka. Jazyková situace slovenských Rusínů je ovšem unikátní v tom, že výrazně vyšší počet obyvatel uvádí rusínštinu jako rodný jazyk, než kolik obyvatel se hlásí k rusínské národnosti. I tato skutečnost ukazuje ze strany Rusínů na nepř́iliš silné povědomí ve vztahu k rusínské národnosti.

\section{Literatura}

\section{Archivní zdroje}

Czambel, Samo [1906]. Slovenská reč 22.

Kontratovič, Irenej [1924]. Otkrytoje pismo do vnimanija Americkoj Slovanskoj Ligi. Russkoe slovo, 15. 11. 1924.

Sbírka zákonů ČSSR, 144/1968 Sb.

Sbírka zákonů Republiky Československé, 102/1922 Sb.

Sbírka zákonů Republiky Československé, 508/1921 Sb.

\section{Elektronické zdroje}

Čislennost i sostav naselenija Zakarpatskoj oblasti po itogam Vseukrainskoj perepisi naselenija 2001 goda [2003]. Gosudarstvennyj komitet statistiki Ukrainy [online]. Dostupné z: <http://2001.ukrcensus.gov .ua/rus/results/general/nationality/zakarpatia> [cit. 19. 11. 2015].

Došková, Kristýna - Fučíková, Veronika - Milenovská, Marie - Mondryk, Romana [2015]. Rusíni na Slovensku. [online]. Dostupné z: <http://pestraevropa.hks.re/2015/Rusini-SK> [cit. 19. 12. 2016].

Kruško, Štefan [2013]. Slovenskí presídlenci [online]. Dostupné z: <http://bit.ly/presidlenci> [cit. 25. 3. 2017].

Obyvatel'stvo podla národnosti, materinského jazyka a pohlavia [2011]. Štatistický úrad Slovenskej republiky [online]. Dostupné z: <www.statistics.sk> [cit. 7. 12. 2016].

Obyvatel'stvo podla pohlavia a národnosti [2011]. Štatistický úrad Slovenskej republiky [online]. Dostupné z: <http://census2011.statistics.sk/tabulky.html> [cit. 19. 11. 2015].

Pop, Ivan [2014]. Osobnosti našich dějín [online]. Dostupné z: <http://www.rusyn.sk/ivan-pop-osobnosti -nasich-dejin-strypsky-hijador> [cit. 11. 1. 2017].

Rusínska národnostná menšina [2016]. Úrad vlády SR [online]. Dostupné z: <http://www.narodnostnemensiny.gov.sk/rusinska-narodnostna-mensina> [cit. 14. 12. 2016].

Rusyn [2016]. SIL International [online]. Dostupné z: <https://www.ethnologue.com/language/rue > [cit. 7. 12. 2016]. 
Ruthenian in Ukraine [2016]. Joshua Project [online]. Dostupné z: <https://joshuaproject.net/people _groups/14601/UP> [cit. 7. 12. 2016].

Stanovništvo prema nacionalnoj pripadnosti [2011]. Republika Srbija, Republički zavod za statistiku [online]. Dostupné z: <http://webrzs.stat.gov.rs/WebSite/Public/ReportResultView.aspx?rptId=1210> [cit. 7. 12. 2016].

Stenoprotokol 148. schůze Národního shromáždění [1931]. 26. 11. 1931 [online]. Dostupné z: <http:// www.psp.cz/eknih/1929ns/ps/stenprot/148schuz/s148013.htm> [cit. 17. 12. 2016].

Šoltés, Peter [2014]. Slovensko-rusínske spolužitie v minulosti [online]. Dostupné z: <http://www.rusynacademy.sk/slovak/sl_history.html> [cit. 16.11.2016].

\section{Knihy a studie}

Alter, Peter T. [1996]. The creation of multi-ethnic peoplehood. Journal of American Ethnic History 15 (3): 3-21.

Bobák, Ján [2000]. Rusíni a Akcia P. Kultúra 16/2000.

Fučíková, Veronika [2016]. Vliv politické situace na vývoj rusínské etnicity. Praha: ČZU.

Gajdoš, Marián - Konečný, Stanislav [1994]. Postavenie Rusínov-Ukrajincov na Slovensku 1948-1953. Praha: Ústav pro soudobé dějiny AV ČR.

Gajdoš, Marián - Konečný, Stanislav [2005]. Rusíni a Ukrajinci na Slovensku v procesoch transformácie (1989-1995). Prešov: Universum.

Homzová, Aneta [2010]. Dva cyrilské rukopisy z karpatskej proveniencie vo svetle jazykových kontaktov. Brno: Masarykova univerzita.

Jakešová, Elena [1988]. Reemigrácia a vystahovalectvo obyvatelstva Slovenska v období po vzniku Československej republiky. Slováci v zahraničí. Martin: Matica slovenská.

Klepetko, Roman [2014]. Současná role národní identity aneb proč (ne)stavíme památníky. Kulturnístudia 1: 64-79.

Kokaisl, Petr [2014]. Po stopách Slovákư ve východní Evropě. Praha: Nostalgie.

Kushko, Nadiya [2007]. Literary Standards of the Rusyn Language: The Historical Context and Contemporary Situation. The Slavic and East European Journal 51 (1): 111-132.

Lupčo, Martin [2013]. Sondáž do typológie konfliktov medzi gréckokatolickou a pravoslávnou cirkvou v období normalizácie. Historica Olomucensia 45: 247-264.

Magocsi, Paul R. [2014]. Národ odnikud: ilustrované dějiny karpatských Rusínů. Užhorod: V. Pad’ak.

Marčuk, Vasyl - Marčuk, Natalija [2012]. Etnični osoblyvosti rusyniv. Etnos i kultura 2011-2012 (8-9): 22-27.

Plišková, Anna [2007]. Rusinský jazyk na Slovensku: náčrt vývoja a súčasné problémy. Prešov: Metodicko-pedagogické centrum.

Rehák, Martin [2013]. Analýza etnických minoritných kuchyní a ich vplyv na regionálne kuchyne v definovanom regióne na území Slovenskej republiky. Brno: Vysoká škola obchodní a hotelová.

Shea, John J. [1999]. Light From the East. America 181 (15).

Stolarik, M. Mark [2010]. Slovak Immigrants Come to Terms with Religious Diversity in North America. The Catholic Historical Review 96 (1): 56-84.

Sulitka, Andrej [2016]. K otázce etnické identity Rusínů v České republice. Český lid 103 (3): 451-472.

Ševčenko, K. [2011]. Rusiny v Slovakii v 1920- egg.: osnovnyje čerty etnokul'turnogo i političeskogo razvitija. Rossijskije i slavjanskije issledovanija. Minsk: BGU.

Šš̌ková, Rủžena - Mušinka, Mikuláš - Mušinka, Alexander [2005]. Ukrajinská nářečí Slovenska: výzkum a zvukové zápisy z let 1957-1967. Praha: Slovanský ústav AV ČR.

Švagrovský, Štefan - Ondrejovič, Slavomír [2004]. Východoslovenský jazykový separatizmus v 19. a 20. storočí. Slovenská reč 69 (3): 129-150.

Vévoda, Rudolf [2000]. Řeckokatolická církev za komunistické diktatury. Getsemany 112 (12): 317. 
Petr Kokaisl je garantem oboru Hospodářská a kulturní studia na Provozně ekonomické fakultě ČZU v Praze. Mezi jeho výzkumné zájmy patři kulturní antropologie, etnické minority, geografie náboženství a transformace společnosti. 